\title{
ISOSTERIC HEAT, ENTROPY, AND GIBBS FREE ENERGY OF PUMPKIN SEEDS (Cucurbita moschata)
}

\author{
Luciana P. Teixeira ${ }^{1 *}$, Ednilton T. de Andrade ${ }^{2}$, Ivano A. Devilla ${ }^{3}$
}

\author{
1*Corresponding author. Universidade Federal Fluminense/ Niterói - RJ, Brasil. Email: lucianapteixeira@yahoo.com.br
}

\section{KEYWORDS}

quality, energy, thermodynamic properties, oil.

\begin{abstract}
To maintain seed and soil quality of pumpkin, energy knowledge associated with processing and storage stages is strategic for the optimization of the thermodynamic processes needed for product stabilization. Thus, the objective of this study was to determine isosteric heat, differential entropy, and Gibbs free energy within a temperature range from 20 to $70^{\circ} \mathrm{C}$, and relative air humidity levels between 10.75 and $85.11 \%$. The study was based on empirical data for water activity determination. As a result, we verified that as moisture content decreased, the integral isosteric heat of the product increased from 2502.35 to $6231.17 \mathrm{~kJ} \mathrm{~kg}^{-1}$, differential entropy raised from 1.18 to 12.43 $\mathrm{kJ} \mathrm{kg}^{-1} \mathrm{~K}^{-1}$, and Gibbs free energy ranged from -243.84 to $-432.59 \mathrm{~kJ} \mathrm{~kg}^{-1}$. Thus, we concluded that the lower the water availability in seeds, the greater the energetic requirement for its removal, as there is a major interaction between water and the product (seeds), indicating an increasingly less spontaneous desorption process.
\end{abstract}

\section{INTRODUCTION}

From pumpkin (Cucurbita moschata), both the fruit and its grains are consumed, which can be used roasted or as raw material for oil production liable to be utilized in food and energy (Adams et al., 2012; Veronezi \& Jorge, 2012; Schinas et al., 2009). Pumpkin grains are consumed in several countries, being important sources of proteins (32 to $40 \%$ ), lipids (44 to $50 \%$ ) and fibers (23 to $27 \%$ ), rich in fatty acids, mono and polyunsaturated (Trucom, 2006), submitting an equivalent production to $450 \mathrm{~g}$ of oil per each $1 \mathrm{~kg}$ of pressed grains, with approximately $30 \%$ of moisture content, on wet basis (wb) (El-Soukkary, 2001).

After removed from the fruit, these grains, which present germinative characteristics easily influenced by their moisture content alteration (Bee \& Barros, 1999), when exposed to the environment can also suffer deterioration due to microorganisms attack and enzymatic modifications. For this reason, the proper application of techniques and processes capable of controlling moisture content is essential to ensure maintenance stability of product quality.

In the same way, the knowledge about grains and seeds properties are decisive for analyses related to heat and mass transfer effects during the drying and storage of products (Resende et al., 2011, Caetano et al., 2012, Silva et al., 2016), energy requirement for drying performance, and for oil quality maintenance in the inner grain (Rosa \& Telis-Romero, 2013). The study of such characteristics is important since it covers thermodynamic analysis involved in adsorption and desorption processes, allowing optimization and a better understanding of water properties in relation to the product, and energy calculation requirements associated with heat and mass transfer in these biological products (Oliveira et al., 2013).

For a clearer analysis on the biological components and water interactions in products, as well as to verify sorption process spontaneity, specific thermodynamic studies can be adopted, such as integral isosteric heat of sorption, liquid isosteric heat of sorption or differential enthalpy, entropy, and Gibbs free energy. According to Thys et al. (2010), data on product hygroscopic characteristics are used to determine these thermodynamic properties.

According to Corrêa et al. (2010), through integral isosteric heat variations, due to product moisture content, water molecule changes and interactions among product constituents can be determined, as well as to analyze through entropy the energy associated with bonding or repulsion forces in the system, which is related to waterproduct spatial arrangement relation. In a complementary way to this study, there is Gibbs free energy, which relates

${ }^{2}$ Universidade Federal de Lavras/ Lavras - MG, Brasil.

${ }^{3}$ Universidade Estadual de Goiás/ Anápolis - GO, Brasil.

Received in: 3-22-2017

Accepted in: 9-12-2017 
to the required energy for transferring water molecules from a solid surface to vapor state or vice versa, that is, represents the measurement of the system effort to perform desorption or adsorption processes (Oliveira et al., 2014).

Taking into account the importance associated with oil production from pumpkin grains, for both food and energy purposes, studying the required energy demand for the proper processing of products would allow an optimization of processes and improve accuracy in product quality control. For this reason, the objective of this paper was to determine isosteric heat, entropy, and Gibbs free energy of pumpkin grains under controlled temperature conditions and product moisture content.

\section{MATERIAL AND METHODS}

This study was carried out at Federal Fluminense University. For the assessments, pumpkin grains with an initial moisture content of $0.096 \mathrm{db}$ were used. To determine the amount of water activity $\left(a_{w}\right)$ required to analyze the isosteric heat of sorption for pumpkin grains, an equilibrium moisture content equation (Equation 1) was employed, adjusted for Modified Halsey model, at temperature ranges of 20 to $70^{\circ} \mathrm{C}$, and relative air humidity levels between 10.75 and $85.11 \%$, defined through hygroscopicity study developed by Teixeira et al. (2014). This equation, adjusted for the pumpkin grains, presented determination coefficient of $98.30 \%$, mean relative error of $3.24 \%$, and mean estimated error of 0.0105 .

$$
\mathrm{X}_{\mathrm{e}}=\left[\frac{\exp (-8.3762-0.0225 . \mathrm{T})}{-\ln \left(a_{\mathrm{W}}\right)}\right]^{1 / 3.8973}
$$

where,

$$
\begin{aligned}
& \text { Xe - equilibrium moisture content on a dry basis; } \\
& \mathrm{T} \text { - temperature, in }{ }^{\circ} \mathrm{C} \text {; } \\
& \mathrm{a}_{\mathrm{w}} \text { - water activity, in decimal. }
\end{aligned}
$$

Once water activity was determined, isosteric heat or enthalpy was forecasted through the estimation of the liquid isosteric heat of sorption (or differential enthalpy), by means of Sopade and Ajisegiri exponential model (Equation 2), and Clausius-Clapeyron modified equation (Equation 3). In this case, equilibrium moisture content and temperature (Wang \& Brennan, 1991) are also considered.

$$
\begin{aligned}
& \mathrm{q}_{\mathrm{st}}==\mathrm{A} \exp (-\mathrm{B} \mathrm{U}) \\
& \ln \left(\mathrm{a}_{\mathrm{w}}\right)=-\left(\mathrm{qst}_{\mathrm{e}}\right) \mathbf{1} / \mathrm{Tabs}_{\mathrm{a}}+\mathrm{C}
\end{aligned}
$$

where, qst - liquid isosteric heat of sorption, in $\mathrm{kJ} \mathrm{kg}^{-1}$;

Tabs - absolute temperature, in $\mathrm{K}$;

$\mathrm{R}$ - universal gas constant for water vapor, $0.4619 \mathrm{~kJ}$ $\mathrm{kg}^{-1} \mathrm{~K}^{-1}$

A, B, C - adjustment coefficients.

For integral isosteric heat forecast, which also adds to the liquid isosteric heat of sorption the energy associated with the latent heat of free water vaporization (Equation 4), [eq. (5)] was applied (Chaves et al., 2015).

$$
\begin{aligned}
& \mathrm{L}=2502.2-2.39 . \mathrm{Tm} \\
& \mathrm{Qst}=\mathrm{qst}+\mathrm{L}
\end{aligned}
$$

where,

Qst - liquid isosteric heat of sorption, in $\mathrm{kJ}^{\mathrm{kg}-1}$;

$\mathrm{L}$ - latent heat of free water vaporization, in $\mathrm{kJ}^{\mathrm{kg}-1}$;

$\mathrm{Tm}$ - study range mean temperature, in ${ }^{\circ} \mathrm{C}$.

Yet for order or disorder degree analysis and characterization in the water-product system, entropy (Equation 6) was measured associated with the product, according to Goneli et al. (2010).

$$
\Delta \mathrm{S}=\frac{\Delta \mathbf{q}_{\mathrm{st}}-\Delta \mathrm{G}}{\mathrm{T}_{\mathrm{abs}}}
$$

where,

$\Delta \mathrm{S}$ - differential entropy of sorption, in $\mathrm{kJ} \mathrm{kg}^{-1} \mathrm{~K}^{-1}$;

$\Delta \mathrm{G}$ - Gibbs free energy, in $\mathrm{kJ} \mathrm{kg}^{-1}$.

For spontaneity analysis of water gain and loss process between product and environment, as indicated by Oliveira et al. (2014), Gibbs free energy calculation was enforced. For Gibbs free energy negative values, the process is spontaneous, and for positive values, it is nonspontaneous, yet when it is zero, then equilibrium was reached in relation to process spontaneity (Corrêa et al., 2010). According to Oliveira et al. (2013), Gibbs free energy can be estimated using [eq. (7)].

$$
\Delta \mathrm{G}=\mathbf{R}_{\mathrm{wa}} \mathrm{T}_{\mathrm{abs}} \ln \left(\mathbf{a}_{\mathrm{w}}\right)
$$

\section{RESULTS AND DISCUSSION}

Equilibrium moisture content empirical data, related to hygroscopicity analysis, adopted for isosteric heat, entropy and Gibbs free energy calculations are available in Table 1. Equation 1 was used in determining the water activity in pumpkin seeds at temperatures between 20 and $70^{\circ} \mathrm{C}$. Table 2 discloses water activity values $\left(\mathrm{a}_{\mathrm{w}}\right)$, in decimal, for pumpkin grains, determined by Modified Halsey model. 
TABLE 1. Equilibrium moisture content of pumpkin grain at different temperatures and relative air humidities.

\begin{tabular}{ccc}
\hline Relative Humidity $(\%)$ & Temperature $\left({ }^{\circ} \mathrm{C}\right)$ & Mean equilibrium moisture content $(\mathrm{db})$ \\
\hline 11.31 & 20 & 0.0858 \\
33.07 & 20 & 0.0976 \\
54.38 & 20 & 0.1234 \\
85.11 & 20 & 0.1652 \\
11.28 & 30 & 0.0808 \\
21.61 & 30 & 0.0825 \\
32.44 & 30 & 0.0952 \\
51.4 & 30 & 0.1148 \\
83.62 & 30 & 0.1488 \\
11.03 & 55 & 0.0727 \\
29.93 & 55 & 0.0747 \\
50.15 & 55 & 0.0940 \\
80.70 & 55 & 0.1290 \\
10.75 & 70 & 0.0653 \\
27.77 & 70 & 0.0683 \\
49.70 & 70 & 0.0888 \\
79.49 & 70 & 0.1126 \\
\hline
\end{tabular}

TABLE 2. Water activity values $\left(\mathrm{a}_{\mathrm{w}}\right)$ estimated by Modified Halsey model for the pumpkin grains, according to temperature and equilibrium moisture content.

\begin{tabular}{|c|c|c|c|c|}
\hline \multirow{2}{*}{ Equilibrium moisture content (db) } & \multicolumn{4}{|c|}{ Temperatures $\left({ }^{\circ} \mathrm{C}\right)$} \\
\hline & 20 & 30 & 55 & 70 \\
\hline 0.065 & 0.0022 & 0.0076 & 0.0617 & 0.1369 \\
\hline 0.068 & 0.0059 & 0.0166 & 0.0967 & 0.1887 \\
\hline 0.073 & 0.0181 & 0.0405 & 0.1607 & 0.2711 \\
\hline 0.075 & 0.0268 & 0.0555 & 0.1922 & 0.3081 \\
\hline 0.081 & 0.0696 & 0.1191 & 0.2971 & 0.4205 \\
\hline 0.083 & 0.0859 & 0.1407 & 0.3269 & 0.4501 \\
\hline 0.086 & 0.1212 & 0.1854 & 0.3825 & 0.5035 \\
\hline 0.089 & 0.1582 & 0.2292 & 0.4318 & 0.5490 \\
\hline 0.094 & 0.2284 & 0.3074 & 0.5104 & 0.6187 \\
\hline 0.095 & 2.457 & 0.3259 & 0.5277 & 0.6336 \\
\hline 0.098 & 0.2793 & 0.3611 & 0.5594 & 0.6605 \\
\hline 0.113 & 4.816 & 0.5578 & 0.7169 & 0.7885 \\
\hline 0.115 & 0.5084 & 0.5825 & 0.7348 & 0.8025 \\
\hline 0.123 & 0.6003 & 0.6652 & 0.7926 & 0.8471 \\
\hline 0.129 & 0.6508 & 0.7095 & 0.8223 & 0.8696 \\
\hline 0.149 & 0.7818 & 0.8215 & 0.8939 & 0.9231 \\
\hline 0,165 & 0,8487 & 0,8772 & 0,9280 & 0,9481 \\
\hline
\end{tabular}

Through Table 2 data, we could verify that as moisture content and/or temperature increase, there is an upsurge in water activity, indicating an increased water availability in the product. Oliveira et al. (2014) observed the same behavior for jatropha.

Based on water activity data, the liquid isosteric heat of sorption was determined from the angular coefficients of curves according to $\ln \left(\mathrm{a}_{\mathrm{w}}\right) \times\left(\mathrm{T}_{\mathrm{abs}}{ }^{-1}\right)$, shown in Figure 1, for different equilibrium moisture contents, as indicated by [eq. (3)].
From angular coefficients measurement, applied to [eq. (3)], the isosteric heat values of pumpkin seeds could be established. According to Equation 4, the average empirical temperature used as latent heat of free water vaporization was $42.94{ }^{\circ} \mathrm{C}$, resulting in a latent heat of vaporization of $2399.57 \mathrm{~kJ} \mathrm{~kg}^{-1}$. Table 3 reports liquid and integral isosteric heat of sorption values and their corresponding moisture contents and angular coefficients. 


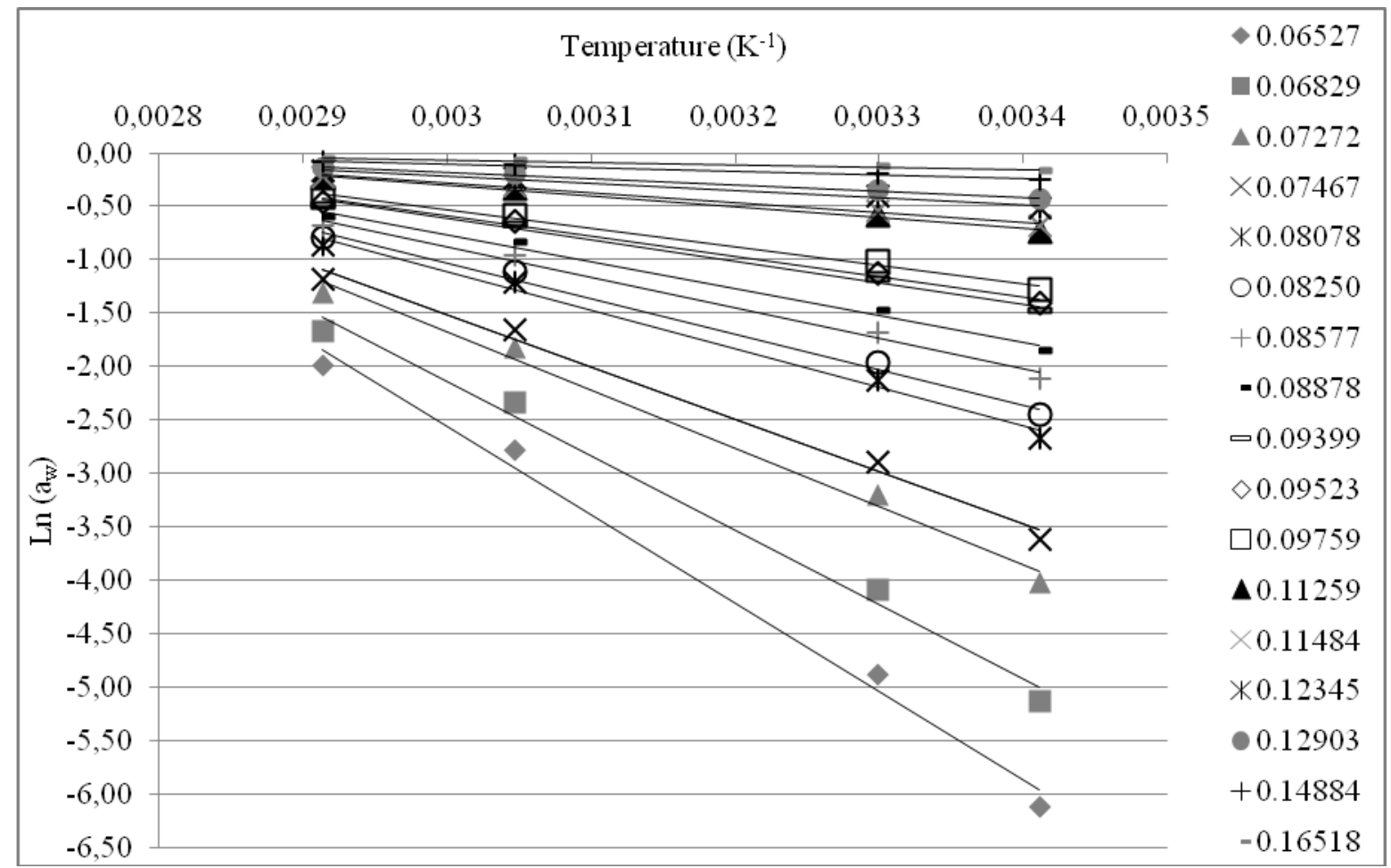

FIGURE 1. Angular coefficient values for different equilibrium moisture contents (db) of the pumpkin grains.

TABLE 3. Liquid and integral isosteric heat values of the pumpkin grains for different equilibrium moisture contents (db).

\begin{tabular}{cccc}
\hline Equilibrium moisture content $(\mathrm{db})$ & Angular Coefficient & $\begin{array}{c}\text { Liquid isosteric heat } \\
\left(\mathrm{kJ} \mathrm{kg}^{-1}\right)\end{array}$ & $\begin{array}{c}\text { Integral isosteric heat } \\
\left.(\mathrm{kJ} \mathrm{kg})^{-1}\right)\end{array}$ \\
\hline 0.065 & 8295.3 & 3831.60 & 6231.17 \\
0.068 & 6956.7 & 3213.30 & 5612.87 \\
0.073 & 5444.3 & 2514.72 & 4914.29 \\
0.075 & 4910.0 & 2267.93 & 4667.50 \\
0.081 & 3613.4 & 1669.03 & 4068.60 \\
0.083 & 3329.2 & 1537.76 & 3937.33 \\
0.086 & 2861.7 & 1321.82 & 3721.39 \\
0.089 & 2500.9 & 1155.17 & 3554.74 \\
0.094 & 2002.6 & 925.00 & 3324.57 \\
0.095 & 1903.5 & 879.23 & 3278.80 \\
0.098 & 1729.7 & 798.95 & 3198.52 \\
0.113 & 991.0 & 457.74 & 2857.31 \\
0.115 & 917.5 & 423.78 & 2823.35 \\
0.123 & 692.2 & 319.73 & 2719.30 \\
0.129 & 582.6 & 269.12 & 2668.69 \\
0.149 & 333.9 & 154.21 & 2553.79 \\
\hline
\end{tabular}

Figure 2 and Table 3 results show that as equilibrium moisture increases, angular coefficient decreases and, consequently, liquid and integral isosteric heats decline as well (Thys et al., 2010). From these data attainment, we reached the equation that provides integral isosteric heat of sorption for the pumpkin grains (Equation 8 ), according to equilibrium moisture content (db) and mean temperature of $42.94{ }^{\circ} \mathrm{C}$. Estimated parameters and determination coefficient values were, respectively,
$\mathrm{A}=90543.14$ and $\mathrm{B}=-48.93$, where $\mathrm{R}^{2}$ was equivalent to $99.5 \%$.

$\mathbf{Q}_{\mathrm{st}}=90543.14 \exp \left(-48.93 \mathrm{U}_{\mathrm{eq}}\right)+2399.57$

From the obtained results, Figure 2 features theoretical and estimated (simulated) values of integral isosteric heat of sorption according to equilibrium moisture content, in $\mathrm{db}$. 




FIGURE 2. Theoretical $\left(\mathrm{Q}_{\mathrm{st}}\right.$ theoretical) and estimated $\left(\mathrm{Q}_{\mathrm{st}}\right.$ simulated) integral isosteric heat of sorption values of the pumpkin grains according to equilibrium moisture content.

Figure 2 makes it clear that as long as moisture content decreases, more energy is needed to remove it, as already mentioned by Oliveira et al. (2014). Thus, the integral isosteric heat of sorption values for the pumpkin grains, in moisture content range from 0.0653 to 0.1652 (db), were observed to vary from 6231.17 to $2502.35 \mathrm{~kJ}$ $\mathrm{kg}^{-1}$. This behavior is corroborated as well by Caetano et al. (2012) for Anacardium othonianum Rizz seeds. Due to liquid isosteric heat or differential enthalpy determination, the differential entropy of sorption could be calculated (Equation 6), considering Gibbs free energy (Equation 7). Table 4 reports related values to the differential entropy of sorption and Gibbs free energy, according to liquid isosteric heat.

TABLE 4. Differential entropy of sorption and Gibbs free energy values according to the liquid isosteric heat of the pumpkin grains.

\begin{tabular}{|c|c|c|c|c|}
\hline $\begin{array}{l}\text { Equilibrium moisture } \\
\text { content }(\mathrm{db})\end{array}$ & $\begin{array}{l}\text { Temperature } \\
\left({ }^{\circ} \mathrm{C}\right)\end{array}$ & $\begin{array}{l}\text { Liquid isosteric heat } \\
\qquad\left(\mathrm{kJ} \mathrm{kg}^{-1}\right)\end{array}$ & $\begin{array}{c}\text { Differential entropy } \\
\text { of sorption } \\
\left(\mathrm{kJ} \mathrm{kg}^{-1} \mathrm{~K}^{-1}\right)\end{array}$ & $\begin{array}{l}\text { Gibbs free energy } \\
\left(\mathrm{kJ} \mathrm{kg}^{-1}\right)\end{array}$ \\
\hline 0.065 & 70 & 3831.60 & 12.43 & -432.59 \\
\hline 0.068 & 70 & 3213.30 & 10.60 & -425.44 \\
\hline 0.073 & 55 & 2514.72 & 8.87 & -397.31 \\
\hline 0.075 & 55 & 2267.93 & 8.11 & -393.29 \\
\hline 0.081 & 30 & 1669.03 & 6.67 & -352.31 \\
\hline 0.083 & 30 & 1537.76 & 6.22 & -349.37 \\
\hline 0.086 & 20 & 1321.82 & 5.64 & -332.59 \\
\hline 0.089 & 70 & 1155.17 & 4.48 & -383.83 \\
\hline 0.094 & 55 & 925.00 & 3.91 & -358.41 \\
\hline 0.095 & 30 & 879.23 & 3.99 & -329.28 \\
\hline 0.098 & 20 & 798.95 & 3.80 & -315.09 \\
\hline 0.113 & 70 & 457.74 & 2.34 & -346.18 \\
\hline 0.115 & 30 & 423.78 & 2.40 & -303.06 \\
\hline 0.124 & 20 & 319.73 & 2.06 & -283.27 \\
\hline 0.130 & 55 & 269.12 & 1.77 & -310.39 \\
\hline 0.149 & 30 & 154.21 & 1.39 & -266.74 \\
\hline 0.165 & 20 & 102.78 & 1.18 & -243.84 \\
\hline
\end{tabular}

Since the adopted empirical method was based on an adsorption process, from the results shown in Table 4, we may infer that the greater the interaction of water molecules with product constituents (lower equilibrium moisture content), the larger the energy needed for transferring these molecules from the solid surface of the product to vapor state. Hence, desorption process presents increasingly less spontaneous characteristics. Therefore, for the pumpkin grains, as equilibrium moisture content is reduced, the water absorption in the product becomes progressively more spontaneous. Rosa \& Telis-Romero (2013) also noticed this behavior for orange seeds and by Silva et al. (2016) for pepper seeds.

Mathematically, the relationship among enthalpy, entropy, and Gibbs free energy can demonstrate this trend. As enthalpy (isosteric heat) and entropy are positive, then Gibbs free energy is negative, characterizing a desorption process becoming increasingly less spontaneous when 
there is a decrease in the moisture content of the product. In addition, through Gibbs free energy and entropy results, we can confirm that the energetic analysis of sorption process can be influenced by both moisture content and temperature.

\section{CONCLUSIONS}

Moisture content influences thermodynamic properties of pumpkin seeds, as well as technical parameters definition over processing and storage stages.

The lower the water availability in the product, the greater the energy required for its removal, and the stronger the interaction between water and product.

As the moisture content in product decreases, integral isosteric heat, differential entropy, and Gibbs free energy increases, in absolute values.

Gibbs free energy revealed a negative signal, indicating that desorption process becomes increasingly less spontaneous as product moisture content decreases.

\section{REFERENCES}

Adams GG, Imran S, Wang S, Mohammed A, Kok MS, Gray DA, Channell GA, Harding SE (2012) Extraction, isolation and characterization of oil bodies from pumpkin seeds for therapeutic use. Food Chemistry 134:1919-1925 DOI: http://dx.doi.org/10.1016/j.foodchem.2012.03.114

Bee RA, Barros ACSA (1999) Sementes de abóbora armazenadas em condições de vácuo. Revista Brasileira de Sementes 21(2):120-126.

Caetano GS, Sousa KA, Resende O, Sales JF, Costa LM (2012) Higroscopicidade desementesdecaju-de-árvore-docerrado. Pesquisa Agropecuária Tropical 442(4):437-445.

Chaves TH, Resende O, Oliveira DEC, Siqueira VC, Smaniotto TAS, Sousa KA (2015) Isotermas e calor isostérico das sementes de pinhão-manso. Engenharia na Agricultura 23(1):9-18.

Corrêa PC, Oliveira GHH, Botelho FM, Goneli ALD, Carvalho FM (2010) Modelagem matemática e determinação das propriedades termodinâmicas do café (Coffea arabica L.) durante o processo de secagem. Revista Ceres 57(5):595-601. DOI: http://dx.doi.org/10.1590/S0034-737X2010000500005

El-Soukkary FA (2001) Evaluation of pumpkin seed products for bread fortification. Plant Foods Human Nutrition 56(4):365-84. DOI: http: //dx.doi.org/10.1023/A: 1011802014770

Goneli ALD, Corrêa PC, Oliveira GHH, Botelho FM (2010) Water desorption and thermodynamic properties of okra seeds. Transaction of the ASAE 53(1):191-197. DOI: http://dx.doi.org/10.13031 / 2013.29486

Oliveira DEC, Resende O, Chaves TH, Sousa KA, Smaniotto TAS (2014) Propriedades termodinâmicas das sementes de pinhão manso. Bioscience Journal 30:147157.
Oliveira DEC, Resende O, Smaniotto TAS, Sousa KA, Campos RC (2013) Propriedades termodinâmicas de grãos de milho para diferentes teores de água de equilíbrio. Pesquisa Agropecuária Tropical 43(1):50-56.

Resende O, Ullmann R, Siqueira VC, Chaves TH, Ferreira LU (2011) Modelagem matemática e difusividade efetiva das sementes de pinhão-manso (Jatropha curcas L.) durante a secagem. Engenharia Agrícola 31(6):1123-1135. DOI: http://dx.doi.org/10.1590/S010069162011000600010

Rosa DP, Telis-Romero J (2013) Study of the enthalpyentropy mechanism from water sorption of orange seeds (C. sinensis cv. Brazilian) for the use of agro-industrial residues as a possible source of vegetable oil production. Food Science and Technology 33(1). DOI: http://dx.doi.org/10.1590/S0101-20612013000500015

Schinas P, Karavalakis G, Davaris C, Anastopoulos G, Karonis D, Zannikos F, Stournas S, Lois E (2009) Pumpkin (Cucurbita pepo L.) seed oil as an alternative feedstock for the production of biodiesel in Greece. Biomass and Bioenergy 33:44-49. DOI: http://doi.org/10.1016/j.biombioe.2008.04.008

Silva HW, Costa LM, Resende O, Oliveira DEC, Soares RS, Vale LSR (2016) Thermodynamic properties of pepper seeds - variety 'Cabacinha'. Scientific 44(1):14-22. DOI: http://dx.doi.org/10.15361/19845529.2016v44n1p14-22

Teixeira LP, Andrade ET, Figueira VG (2014) Determinação do equilíbrio higroscópico dos grãos de abóbora (Cucurbita moschata). In: Congresso Brasileiro de Engenharia Agrícola. Campo Grande, MS. Available at: http://www.sbea.org.br/conbea/2014/anais/ R0572-1.pdf

Thys RCS, Noreña CPZ, Marczak LDF, Aires AG, Cladera-Olivera F (2010) Adsorption isotherms of pinhão (Araucaria angustifolia seeds) starch and thermodynamic analysis. Journal of Food Engineering 100(3):468-473. DOI: http://dx.doi.org/10.1016/j.jfoodeng.2010.04.033

Trucom C (2006) A importância da linhaça na saúde. São Paulo, Alaúde. 152p.

Veronezi CM, Jorge N (2012) Aproveitamento de sementes de abóbora (Cucurbita sp) como fonte alimentar. Revista Brasileira de Produtos Agroindustriais 14(1):113124. DOI: http://dx.doi.org/10.15871/15178595/rbpa.v14n1p113-124

Wang N, Brennan JG (1991) Moisture sorption isotherm characteristics of potatoes at four temperatures. Journal of Food Engineering 14(1):269-287. DOI: https://dx.doi.org/10.1016/0260-8774(91)90018-N 